\title{
Relationship between functional capacity, performance and symptoms in hospitalized patients with heart failure
}

\author{
Relação entre capacidade funcional, desempenho e sintomas em pacientes internados com insuficiência cardíaca \\ Relación entre capacidad funcional, rendimiento y síntomas en pacientes hospitalizados con insuficiencia cardíaca
}

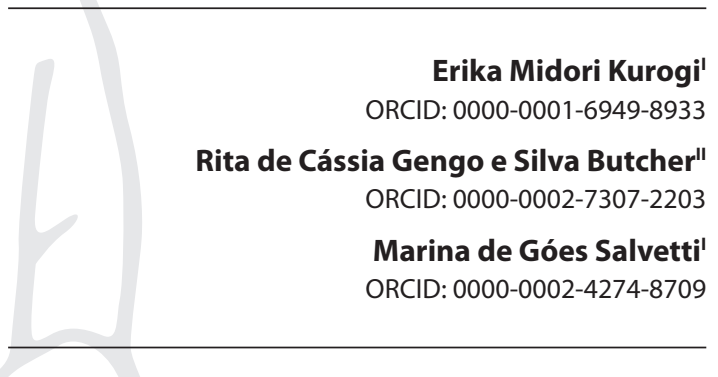

'Universidade de São Paulo. São Paulo, São Paulo, Brazil. "Connell School of Nursing. Chestnut, United States.

How to cite this article: Kurogi EM, Butcher RCGS, Salvetti MG. Relationship between functional capacity, performance and symptoms in hospitalized patients with heart failure.

Rev Bras Enferm. 2020;73(4):e20190123. doi: http://dx.doi.org/10.1590/0034-7167-2019-0123

Corresponding author:

Marina de Góes Salvetti

E-mail:mgsalvetti@usp.br

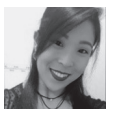

EDITOR IN CHIEF: Antonio José de Almeida Filho ASSOCIATE EDITOR: Fátima Helena Espírito Santo

Submission: 02-22-2019

Approval: 09-04-2019

\begin{abstract}
Objectives: to evaluate the prevalence of symptoms in heart failure patients and to investigate the relationship between symptoms, functional capacity and performance. Methods: crosssectional study, developed at a hospital specializing in cardiology. The sample $(n=170)$ consisted of patients with heart failure, assessed by means of a sociodemographic form, New York Heart Association Functional Class, Edmonton Symptom Rating Scale and Karnofsky Physical Performance Scale. Analyzes were performed using Spearman's Correlation and Pearson's Chi-Square test. Results: dyspnea, fatigue and edema were the main symptoms that led to the search for health services. During hospitalization, the main symptoms were anxiety, sleep disturbance and sadness. Weak negative correlations were observed between functionality, functional class, and symptom overload. Conclusions: the prevalence of symptoms was high and changed throughout the hospitalization period. Patients with poorer functional capacity and poorer performance had greater symptom overload.

Descriptors: Signals and Symptoms; Nursing; Heart Failure; Inpatients; International Classification of Functionality.
\end{abstract}

\section{RESUMO}

Objetivos: avaliar a prevalência de sintomas em pacientes com insuficiência cardíaca e investigar a relação entre sintomas, capacidade funcional e desempenho. Métodos: estudo transversal, desenvolvido em hospital especializado em cardiologia. A amostra $(n=170)$ foi composta por pacientes com insuficiência cardíaca, avaliados por meio de formulário sociodemográfico, Classe Funcional da New York Heart Association, Escala de Avaliação de Sintomas de Edmonton e Escala de Desempenho Físico de Karnofsky. Foram feitas análises através da Correlação Spearman e teste Chi-Quadrado de Pearson. Resultados: dispneia, fadiga e edema foram os principais sintomas que levaram à busca pelo serviço de saúde. Durante a internação, os principais sintomas foram ansiedade, alterações do sono e tristeza. Observaram-se correlações negativas fracas entre funcionalidade, classe funcional e sobrecarga de sintomas. Conclusões: a prevalência de sintomas foi elevada e se modificou ao longo do período de internação. Pacientes com pior capacidade funcional e pior desempenho apresentaram maior sobrecarga de sintomas.

Descritores: Sinais e Sintomas; Enfermagem; Insuficiência Cardíaca; Pacientes Internados; Classificação Internacional de Funcionalidade.

\section{RESUMEN}

Objetivos: evaluar la prevalencia de síntomas en pacientes con insuficiencia cardíaca e investigar la relación entre los síntomas, la capacidad funcional y el rendimiento. Métodos: estudio transversal, desarrollado en un hospital especializado en cardiología. La muestra $(n=170)$ consistió en pacientes con insuficiencia cardíaca, evaluados mediante una forma sociodemográfica, New York Heart Association Functional Class, Edmonton Symptom Rating Scale y Karnofsky Physical Performance Scale. Los análisis se realizaron utilizando la Correlación de Spearman y la prueba de Chi-cuadrado de Pearson. Resultados: disnea, fatiga y edema fueron los principales síntomas que llevaron a la búsqueda de servicios de salud. Durante la hospitalización, los síntomas principales fueron ansiedad, trastornos del sueño y tristeza. Se observaron correlaciones negativas débiles entre funcionalidad, clase funcional y sobrecarga de síntomas. Conclusiones: la prevalencia de síntomas fue alta y cambió a lo largo del período de hospitalización. Los pacientes con peor capacidad funcional y peor rendimiento tuvieron una mayor sobrecarga de síntomas.

Descriptores: Signos y Síntomas; Enfermería; Insuficiencia Cardíaca; Pacientes Internados; Clasificación Internacional de Funcionalidad. 


\section{INTRODUCTION}

Heart failure (HF) is a complex clinical syndrome that results from the heart's inability to deliver oxygen to tissues to meet metabolic demands. It affects 6.5 million Brazilians and 5.7 million Americans ${ }^{(1-3)}$. Estimates indicate that the prevalence of HF will increase by $46 \%$ over the period 2012-2030, resulting in over 8 million people with the disease in Brazil ${ }^{(1-3)}$. In addition, HF is the main cause of hospitalization in patients over 60 years of age in our country ${ }^{(3-6)}$, being responsible for high mortality rates $^{(3-7)}$.

HF patients have physical, emotional, social and spiritual symptoms ${ }^{(8)}$. Dyspnea, pain, cough, depression, fatigue, nausea, constipation, sleep disorders and anxiety are the most common symptoms in HF patients ${ }^{(1-2,5,9-11)}$. These symptoms usually occur concomitantly, and their intensity tends to increase over time, despite therapeutic optimization ${ }^{(12)}$. In this context, symptom management is a priority for patients. In the Evaluation Study of Congestive Heart Failure and Pulmonary Artery Catheterization Effectiveness (ESCAPE) trial, most patients would trade longer survival for better symptom control ${ }^{(13)}$. However, symptom overload in HF patients is a challenge in disease management, especially with the increased longevity of these patients ${ }^{(14)}$.

These symptoms negatively affect the perception of wellbeing and quality of life, causing a sense of loss of autonomy. They interfere with social relations and are associated with more visits to the emergency service, hospitalization and death $s^{(2,5,14-18)}$. Comprehensive symptom assessment is therefore an essential component of improving health and reducing exacerbations and hospitalizations ${ }^{(19)}$. The absence of gold standard measures ${ }^{(20)}$ for symptom overload assessment in HF patients compromises the generalization of data available in the literature.

Considering that HF is a highly prevalent syndrome and the intensity of its symptoms interferes with the quality of life, it is necessary to investigate the overload of symptoms in these patients and their relationship with systemic, functional, emotional and social outcomes.

\section{OBJECTIVES}

To assess the prevalence of symptoms in heart failure patients and to investigate the relationship between symptoms, functional capacity and performance.

\section{METHODS}

\section{Ethical aspects}

The study was developed according to national and international ethical recommendations for research with human beings. The project was approved by the Research Ethics Committee of University of Sao Paulo School of Nursing (USP) and the Ethics Committee for analysis of research projects at Hospital das Clínicas from Faculty of Medicine of USP (HCFMUSP). All participants received information about the study objectives, and those who agreed to participate signed two copies of the Free and Informed Consent Form.

\section{Type of study}

A cross-sectional study developed at HCFMUSP's Heart Institute (InCor - Instituto do Coração). Population included HF patients. The convenience sample consisted of patients older than 18 years who were admitted to the inpatient unit (IU) or intensive care unit (ICU) from May 2018 to October 2018. Patients with lowering of consciousness (Glasgow Coma Scale less than 14), mechanical ventilation, dementia or delirium (described in medical records) were excluded because they could not respond to the data collection instruments. Recruitment and selection were performed based on electronic medical records assessment of patients admitted to the IU.

For data collection, three research instruments were used: form with sociodemographic and clinical data, Edmonton Symptom Assessment System (ESAS) ${ }^{(21)}$ and Karnofsky Performance Status (KPS) ${ }^{(22-23)}$. Sociodemographic data and the ESAS scale were obtained by interview, whose average duration was 15 minutes. KPS data were obtained by direct observation of the researcher at the end of the interview. Other clinical data were obtained by consulting the patient's electronic medical record.

The form with sociodemographic and clinical data was prepared by the authors of the present study, including information on sex, age, symptoms on admission to the emergency room, etiology, comorbidities, number of symptoms reported on hospital admission, functional class on admission and ejection fraction. obtained from the last echocardiogram performed at the institution. Functional classification followed NYHA criteria ${ }^{(24)}$. All clinical information, including functional classification, was collected from the electronic medical record.

ESAS is a brief and easy-to-apply instrument that assesses 10 symptoms: pain, fatigue, nausea, sadness, anxiety, drowsiness, inappetence, malaise, dyspnea, and sleep disorder. The score of each symptom is rated from 0 to 10 . Symptom severity can be categorized as: symptom-free (0), mild (1-3), moderate (4-6), and severe (7-10). The sum of all symptom scores gives the total scale score, which ranges from 0 to 100 points and indicates symptom overload within 24 hours prior to the interview ${ }^{(21)}$.

KPS assesses the functional performance of individuals to perform activities of daily living (ADL), work ability and need for care at the time of the interview. Score ranges from 10 to 100 . Scores from 90 to 100 indicate normal ability to perform activities without the need for special care; 80 , ability to exercise ADL, but presents some signs or symptoms of the disease with effort; 70, ability to take care of oneself (unable to carry on normal activities or to perform active work); 60, need for occasional assistance (still able to provide most of your activities); 50, considerable assistance requirement and frequent medical care; 40, disability (requires special care and assistance); 30, very unable (hospitalization indicated, although death is not imminent); 20, much debilitation (hospitalization required; requiring treatment and active support); 10, dying (lethal processes progressing rapidly) and 0 , death ${ }^{(22-23)}$.

\section{Data analysis}

Data were entered into a spreadsheet and analyzed using the SPSS Statistical Program, version 17.0. Descriptive and inferential analyzes were performed. Quantitative variables were expressed 
as mean (standard deviation - SD) and median, and qualitative variables were expressed as percentages. To analyze the association between sociodemographic and clinical variables, Pearson's Chi-Square test was used, as well as Spearman's Correlation tests. The strength of the correlation between the variables was interpreted according to Mukaka's recommendation ${ }^{(25)}$.

\section{RESULTS}

The results of this study are presented in three stages: sample characterization; description of the prevalence and intensity of symptoms; correlations between symptoms, functional class and functional performance.

\section{Sample characterization}

During the data collection period, 238 patients were assessed for eligibility to participate in the study through the electronic medical record. Of these, 36 were excluded due to exclusion criteria. In addition, 32 patients refused to participate. Thus, 170 patients were included in the study. Sample characterization data are described in Table 1.

Table 1 - Sample's sociodemographic and clinical characterization, São Paulo, 2018

\begin{tabular}{|c|c|}
\hline & n (\%) \\
\hline \multicolumn{2}{|l|}{ Sex } \\
\hline Female & $59(34.7)$ \\
\hline Male & $111(65.3)$ \\
\hline \multicolumn{2}{|l|}{ Age } \\
\hline 18 to 40 & $10(5.9)$ \\
\hline 41 to 59 & $78(45.9)$ \\
\hline 60 and above & $82(48.2)$ \\
\hline \multicolumn{2}{|l|}{ Comorbidities } \\
\hline $\mathrm{SAH}$ & $102(60)$ \\
\hline DM & $60(35.3)$ \\
\hline DLP & $44(25.9)$ \\
\hline Former SMO & $49(28.8)$ \\
\hline Arrhythmia & $69(40.6)$ \\
\hline PM/ICD/ Resynchronizer & $24(14.1)$ \\
\hline Stroke & $16(9.4)$ \\
\hline AMI & $22(12.9)$ \\
\hline CAD & $29(17.1)$ \\
\hline Valve impairment & $41(24.1)$ \\
\hline Kidney impairment & 39 (22.9) \\
\hline Others* & $91(53.5)$ \\
\hline \multicolumn{2}{|l|}{ Etiology } \\
\hline Ischemic CMP & 39 (22.9) \\
\hline Dilated CMP & 27 (15.9) \\
\hline Valve CMP & $24(14.1)$ \\
\hline Chagasic CMP & 19 (11.2) \\
\hline Hypertrophic CMP & $6(3.5)$ \\
\hline $\mathrm{T} / \mathrm{C}$ & $15(8.8)$ \\
\hline No information & $40(23.6)$ \\
\hline \multicolumn{2}{|l|}{ Functional Class } \\
\hline 1 & $4(2.4)$ \\
\hline II & $24(14.1)$ \\
\hline III & $92(54.1)$ \\
\hline IV & $50(29.4)$ \\
\hline
\end{tabular}

Table 1 (concluded)

\section{n (\%)}

\begin{tabular}{lc}
\hline Symptoms on admission to the emergency room & \\
Dyspnea & $146(85.9)$ \\
Fatigue/Tiredness & $138(81.2)$ \\
Edema & $98(57.6)$ \\
Weakness & $83(48.8)$ \\
Pain & $69(40.6)$ \\
Nausea & $62(36.5)$ \\
Inappetence & $53(31.2)$ \\
Dizziness & $39(22.9)$ \\
Cough & $24(14.1)$ \\
Tachycardia & $14(8.2)$
\end{tabular}

Note: CMP - cardiomyopathy; T/C - to clarify; ER - emergency room; ICU - intensive care unit; UI - inpatient unit; $S A H$ - systemic arterial hypertension; DM - diabetes mellitus; $D L P$ - hypercholester olemia; former SMO-former smoker; $P M$ - pacemaker; ICD-implantable cardioverter defibrillator; $A M I$ - acute myocardial infarction; $C A D$ - coronary artery disease. Other comorbidities *-smoker; depression; obesity; chronic obstructive pulmonary disease; hypothyroidism; alcoholist; deep vein thrombosis; pulmonary thromboembolism; pulmonary hypertension.

\section{Prevalence and intensity of symptoms}

On admission symptom analysis showed that $60.6 \%$ of patients had 4 or more symptoms, with an average of 4.3 symptoms per patient. At the time of the interview, which occurred on average 10 days after hospitalization, symptom assessment showed that anxiety was the most frequent symptom (72.4\%), followed by sleep disorders (71.2\%) and sadness (58.8\%) (Figure 1).

Symptom intensity assessment showed that the most frequent symptoms (anxiety, sadness and sleep disorder) were also the most intense in the 24 hours prior to the interview (Table 2).

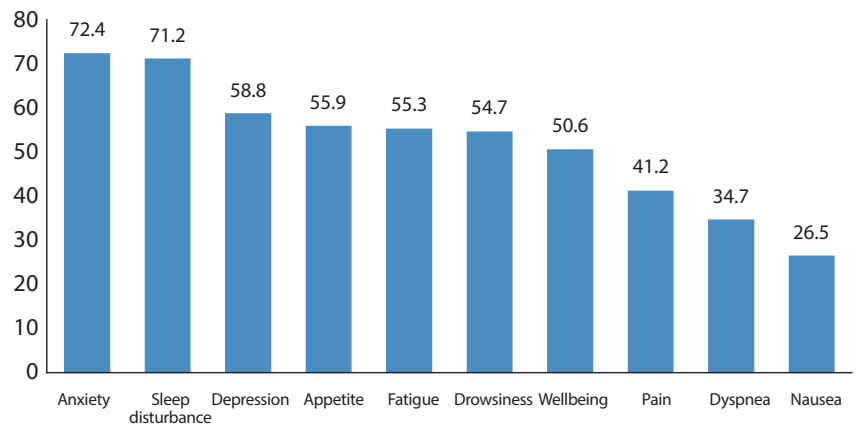

Figure 1 - Prevalence of symptoms in hospitalized patients $(n=170)$ during interview, São Paulo, 2018

Table 2 - Symptom intensity (ESAS) in the 24 hours prior to the interview, São Paulo, 2018

\begin{tabular}{lcc}
\hline & $\mathbf{n = 1 7 0}(\%)$ & Mean (SD); Median \\
\hline Pain & $110(64.7)$ & $2.4(3.2) ; 0$ \\
$\quad$ Absent/Light & $60(35.3)$ & \\
$\quad$ Moderate/Intense & & $2.9(3.3) ; 2.0$ \\
Fatigue & $104(61.2)$ & \\
$\quad$ Absent/Light & $66(38.8)$ & $1.5(2.8) ; 0$ \\
$\quad$ Moderate/Intense & $139(81.8)$ & \\
Nausea & $31(18.2)$ & $4.0(3.9) ; 3.5$ \\
Absent/Light & & \\
Moderate/Intense & $85(50)$ & \\
Depression & $85(50)$ & To be continued \\
Absent/Light & & \\
Moderate/Intense & &
\end{tabular}


Table 2 (concluded)

\begin{tabular}{|c|c|c|}
\hline & $n=170(\%)$ & Mean (SD); Median \\
\hline Anxiety & & $5.0(3.9) ; 5.0$ \\
\hline Absent/Light & 69 (40.6) & \\
\hline Moderate/Intense & $101(59.4)$ & \\
\hline Drowsiness & & $3.2(3.6) ; 2.0$ \\
\hline Absent/Light & $98(57.6)$ & \\
\hline Moderate/Intense & $72(42.4)$ & \\
\hline Appetite & & $3.2(3.4) ; 2.5$ \\
\hline Absent/Light & $97(57.1)$ & \\
\hline Moderate/Intense & $73(42.9)$ & \\
\hline Wellbeing & & $2.9(3.3) ; 2.0$ \\
\hline Absent/Light & $100(58.8)$ & \\
\hline Moderate/Intense & $70(41.2)$ & \\
\hline Shortness of breath & & $1.8(2.8) ; 0$ \\
\hline Absent/Light & $130(76.5)$ & \\
\hline Moderate/Intense & $40(23.5)$ & \\
\hline Sleep disorder & & $4.0(3.3) ; 4.0$ \\
\hline Absent/Light & $76(44.7)$ & \\
\hline Moderate/Intense & $94(55.3)$ & \\
\hline ESAS Total & & $29.4(19.1) ; 26.5$ \\
\hline
\end{tabular}

\section{Correlations between symptoms, functional class and functional performance}

Analysis of the correlation between symptoms indicated a significant, positive and moderate correlation between fatigue and shortness of breath $(r=0.598 ; p<0.001)$ and fatigue and feeling sick $(r=0.500 ; p<0.001)$. Several significant positive and weak correlations were also observed, among other symptoms assessed (Table 3).

Table 3 - Correlation between symptom scores according to ESAS scale, São Paulo, 2018

\begin{tabular}{lcc}
\hline \multicolumn{1}{c}{ Symptoms } & Correlation Coefficient & $\boldsymbol{p}$ value \\
\hline Fatigue and shortness of breath & $\mathrm{r}=0.598$ & $\mathrm{p}<0.001$ \\
Fatigue and wellbeing & $\mathrm{r}=0.500$ & $\mathrm{p}<0.001$ \\
Depression and anxiety & $\mathrm{r}=0.455$ & $\mathrm{p}<0.001$ \\
Shortness of breath and wellbeing & $\mathrm{r}=0.436$ & $\mathrm{p}<0.001$ \\
Nausea and inappetence & $\mathrm{r}=0.378$ & $\mathrm{p}<0.001$ \\
Sleep disorder and appetite & $\mathrm{r}=0.335$ & $\mathrm{p}<0.001$ \\
Sleep disorder and fatigue & $\mathrm{r}=0.333$ & $\mathrm{p}<0.001$ \\
Sleep disorder and depression & $\mathrm{r}=0.328$ & $\mathrm{p}<0.001$ \\
Drowsiness and depression & $\mathrm{r}=0.330$ & $\mathrm{p}<0.001$ \\
Pain and shortness of breath & $\mathrm{r}=0.324$ & $\mathrm{p}<0.001$ \\
Pain and wellbeing & $\mathrm{r}=0.308$ & $\mathrm{p}<0.001$ \\
Sleep disorder and drowsiness & $\mathrm{r}=0.307$ & $\mathrm{p}<0.001$ \\
\hline
\end{tabular}

Table 4 - Relationship between functional class and functional performance, São Paulo, 2018

\begin{tabular}{|c|c|c|c|c|c|c|c|c|c|c|}
\hline & & \multicolumn{8}{|c|}{ Functional Class } & \multirow{3}{*}{$p$ value } \\
\hline & & \multicolumn{2}{|r|}{ I } & \multicolumn{2}{|c|}{ II } & \multicolumn{2}{|c|}{ III } & \multicolumn{2}{|c|}{ IV } & \\
\hline & & $\mathbf{n}$ & $\%$ & $\mathbf{n}$ & $\%$ & $\mathbf{n}$ & $\%$ & $\mathbf{n}$ & $\%$ & \\
\hline \multirow[t]{5}{*}{ KPS } & $90-100$ & 1 & 33.3 & 2 & 66.7 & 0 & 0.0 & 0 & 0.0 & \\
\hline & $70-80$ & 2 & 6.7 & 10 & 33.3 & 11 & 36.7 & 7 & 23.3 & \\
\hline & $50-60$ & 1 & 1.3 & 10 & 12.5 & 47 & 58.8 & 22 & 27.5 & $0.002^{*}$ \\
\hline & $30-40$ & 0 & 0.0 & 2 & 5.1 & 28 & 71.8 & 9 & 23.1 & \\
\hline & $10-20$ & 0 & 0.0 & 0 & 0.0 & 6 & 33.3 & 12 & 66.7 & \\
\hline
\end{tabular}

Note: KPS - Karnofsky Performance Scale; *Pearson's Chi-Square.
Functional performance (KPS) assessment indicated a predominance of patients requiring occasional assistance (47.1\%), followed by patients requiring intensive care $(22.9 \%)$ and mild symptoms (17.6\%). Only $1.8 \%$ of patients were able to perform their activities normally.

Analysis of the relationship between Functional Class (FC) and KPS showed that patients' FC III and IV had significantly worse functional performance (Table 4).

There was a negative and weak correlation between functional performance, functional class and symptom overload indicating that the worse the functionality, the higher the functional class and the greater the symptom overload (Table 5).

Positive correlations were also observed between ejection fraction, functional performance and functional class and symptom overload, as well as a negative correlation between functional class and ejection fraction. This indicates that patients with better functional performance had higher ejection fraction and the higher the functional class the lower the ejection fraction (Table 5).

Table 5 - Correlations between functional class, ejection fraction, symptom overload and functionality, São Paulo, 2018

\begin{tabular}{lcccccc}
\hline & \multicolumn{2}{c}{ FC } & \multicolumn{2}{c}{ EF } & \multicolumn{2}{c}{ ESAS } \\
& \multicolumn{1}{c}{ r } & $\boldsymbol{p}$ value & $\boldsymbol{r}$ & $\boldsymbol{p}$ value & $\mathbf{r}$ & $\boldsymbol{p}$ value \\
\hline KPS & -0.345 & $<0.001$ & +0.237 & 0.002 & -0.414 & $<0.001$ \\
ESAS & +0.167 & 0.029 & -0.050 & 0.518 & & \\
EF & -0.241 & 0.002 & & & & \\
\hline
\end{tabular}

Note: FC - Functional Class; KPS - Karnofsky Performance Scale; ESAS - Edmonton Symptom Assessment System; EF - Ejection Fraction; $r$-Correlation coefficient.

\section{DISCUSSION}

The sociodemographic and clinical characteristics of the present study sample resemble those of other studies that also analyzed HF patients ${ }^{(1-5,10,15,26-30)}$.

The occurrence of concomitant symptoms was verified in the present study at hospital admission and at the time of the interview. The literature indicates that the average number of symptoms in HF patients may vary from seven to 19 . This large variation may be due to the lack of consistency in the concept of symptom overload and the multiplicity of methods available for its assessment ${ }^{(14,20)}$.

Upon admission to the emergency room, dyspnea was the most frequent symptom. Although it is a symptom reported by more than $50 \%$ of HF patients, there seems to be no correlation between reported dyspnea and objective measures such as ejection fraction and cardiac output. In fact, the underlying causes of dyspnea in HF can range from reduced lung compliance to lack of fitness and malnutrition ${ }^{(14,24)}$.

Fatigue, in turn, can affect up to $85 \%$ of HF patients. In the present study, it was the second most frequent symptom reported on admission to the emergency room. The typical catabolic state of $\mathrm{HF}$, changes in skeletal muscle fibers, and respiratory symptoms may be associated with this symptom ${ }^{(3,8,14,31)}$.

About $40 \%$ of patients in the present study reported pain. This data is consistent with other studies with HF patients and often this symptom persists even after hospitalization ${ }^{(3,9)}$. Pain is a symptom that tends to be persistent even after hospitalization. This happens because often this symptom is underestimated by health workers and 
consequently the pain is underdiagnosed ${ }^{(3)}$. It is worth remembering the negative impact of pain, as it is associated with fatigue, loss of functionality, depressive symptoms and sense of wellbeing ${ }^{(3,7,11)}$.

Regarding symptoms presented during hospitalization, that is, anxiety, sleep disorder and depression were the most frequent. In fact, emotional symptoms are common in HF patients $s^{(3-4,7-8,11,26-27,31-32)}$. A literature review showed that up to $70 \%$ of HF patients may have some kind of mood disorder ${ }^{(14)}$. These symptoms negatively affect patients' social relationships and functionality, as well as altering their perception of health ${ }^{(8,26,32)}$.

Interestingly, the results showed that the most frequent symptoms were also reported as the most intense. These symptoms are known to be influenced by several factors. A study found that the symptoms that HF patients experience due to disease decompensation and clinical progress, such as dyspnea, fatigue, pain, edema, inappetence, anxiety and depression, are influenced by the frequency, intensity and duration of each symptom ${ }^{(27)}$. Therefore, it cannot be ruled out that the frequency of symptoms and their duration (although not measured) contributed to the patients perceiving them as more intense.

There was also a high prevalence of anxiety (72.4\%) and sleep disorder (71.2\%) among HF patients. Anxiety was the most frequent and most intense symptom, showing correlation with depression. Anxiety leads to moments of self-exploration and contributes to depressive symptoms and altered perception of wellbeing ${ }^{(4,9)}$.

A study assessing $556 \mathrm{HF}$ patients and analyzing the coexistence of anxiety and depression suggested that effective interventions to reduce sadness could alter anxiety levels in these patients ${ }^{(33)}$. Another study, aimed at assessing the impact of depression and anxiety on mortality and readmission of hospitalized HF patients, found that interventions in this area may influence other important clinical outcomes. Depression and anxiety are independent predictors of death and readmission for decompensated heart failure ${ }^{(34)}$.

Studies show that HF patients experience significant emotional distress that includes depression and anxiety, interruptions in work and social relationships, reduced sexual activity and satisfaction ${ }^{(7,35)}$.

In the present study, sleep disorder was a frequent symptom, being related to lack of appetite, fatigue, depression and shortness of breath. This indicates that this symptom, which often goes unnoticed, should receive great attention from health professionals. Interventions to reduce sleep disorders should be tested in HF patients, as sleep disorders have repercussions on other symptoms and affect their perception of quality of life $\mathrm{f}^{(11)}$.

A study that sought to identify sleep quality and excessive daytime sleepiness in HF patients and correlate with quality of life recruited 23 patients aged 18 to 90 years and functional class II to IV. These patients underwent outpatient follow-up with a multidisciplinary team. It was found that they had a high prevalence of sleep disorders, such as apnea and night waking. These disorders fragment sleep and lead to excessive sleepiness, increased fatigue, decreased pain threshold, and irritability. These factors directly and negatively affect professional, family and social activities ${ }^{(17)}$.

Dyspnea and fatigue were frequent symptoms in the present study and showed a moderate correlation ( $r=0.598 ; p<0.001)$. Both dyspnea and fatigue are symptoms related to worsening functional performance, contributing to social isolation due to its debilitating effects ${ }^{(17)}$.
A study that explored the impact of pain, fatigue and depression on the performance and functional capacity of HF patients found a significant correlation between pain and fatigue, pain and depression, and fatigue and depression. These findings raise the hypothesis that interventions for the management of depressive symptoms and pain may have a positive impact on fatigue, with the potential to improve patients' functional capacity ${ }^{(3)}$.

A weak positive correlation was found between fatigue and feeling sick ( $r=0.500 ; p<0.001)$. One study examined the need for palliative care in HF patients and cancer, comparing symptom overload and sense of well-being. The sample consisted of $60 \mathrm{HF}$ patients and 30 with cancer, and it was found that the feeling of discomfort worsens with the progression of HF. In addition, the progressive worsening of feeling sick is associated with loss of identity and increased dependence, which may be related to fatigue ${ }^{(9)}$.

Other studies have shown that high dyspnea and fatigue scores are related to the increased risk of decompensated heart failure. This increases demand for emergency care and hospitalization, and is associated with higher mortality ${ }^{(9,32,34)}$.

A study that assessed the influence of functional class on patients' functionality found that increased FC score is related to decreased functional performance of HF patients ${ }^{(36)}$. This was also observed in the present study, which observed a negative correlation between functional class and functional performance. These findings highlight the importance of managing the symptoms of these patients, aiming to reduce the negative impact on their activities of daily living. Moreover, by correlating with the KPS and NYHA scale, it is possible to know important clinical information for decision making, such as the indication of palliative care ${ }^{(36)}$.

\section{Study limitations}

The study has limitations that should be pointed out. It was performed in a single health service and with a convenience sample, factors that make it difficult to generalize the findings.

\section{Contributions to the field}

This study highlights the burden of symptoms in HF patients and their relationship to functionality. The identification of the most frequent symptoms in this population may direct the look and performance of nurses in the field of cardiology, as effective symptom management has the potential to improve the functionality and perception of wellbeing of these patients.

\section{CONCLUSIONS}

The prevalence of symptoms in HF patients was high. Dyspnea, fatigue and edema were the main complaints when arriving at the emergency room. After stabilization of the clinical condition during hospitalization in IU, the most frequent and most intense symptoms were anxiety, sleep disorders and sadness.

Several symptoms were positively correlated, with emphasis on fatigue, shortness of breath, wellbeing, anxiety and depression. Functional capacity correlated with functional performance. In addition, functional capacity and performance correlated with symptom overload. 


\section{REFERENCES}

1. Comitê Coordenador da Diretriz de Insuficiência Cardíaca, Rohde LEP, Montera MW, Bocchi EA, Clausell NO, Albuquerque DC. Arq Bras Cardiol. 2018;111(3):436-539. doi: 10.5935/abc.20180190

2. Bocchi EA. Heart failure in South America. Curr Cardiol Rev. 2013;9(2):147-56. doi: 10.2174/1573403X11309020007

3. Conley S, Feder S, Redeker NS. The relationship between pain, fatigue, depression and functional performance in stable heart failure. Heart Lung. 2015; 44(2):107-12. doi: 10.1016/j.hrtlng.2014.07.008

4. Di Naso FC, Pereira JS, Beatricci SZ, Bianchi RG, Dias AS, Monteiro MB. A classe da NYHA tem relação com a condição funcional e qualidade de vida na insuficiência cardíaca. Fisioter Pesqui. 2011;18(2):157-63. doi: 10.1590/S1809-29502011000200010

5. Poffo MR, Assis AV, Fracasso M, Filho OML, Alves SMM, Bald AP, et al. Profile of patients hospitalized for heart failure in tertiary care hospital. Int J Cardiovasc Sci [Internet]. 2017 [cited 2019 Feb 17];30(3):189-98. Available from: http://www.scielo.br/pdf/ijcs/v30n3/2359-4802ijcs-30-03-0189.pdf

6. Kavalieratos D, Gelfman LP, Tycon LE, Riegel B, Bekelman D, Ikejiani DZ, et al. Integration of palliative care in heart failure: rationale, evidence, and future priorities. J Am Coll Cardiol. 2017; 70(15):1919-30. doi: doi: 10.1016/j.jacc.2017.08.036

7. Bocchi EA, Marcondes-Braga FG, Bacal F, Ferraz AS, Albuquerque D, Rodrigues D. Atualização da diretriz brasileira de insuficiência cardíaca crônica. Arq Bras Cardiol [Internet]. 2012 [cited 2019 Fev 17];98(1 Suppl 1):1-33. Available from: http://publicacoes.cardiol.br/ consenso/2012/Diretriz\%20IC\%20Crônica.pdf

8. Pereira DAG, Rodrigues RS, Samora GAR, Lage SM, Alencar MCN, Parreira VF, et al. Capacidade funcional de indivíduos com insuficiência cardíaca avaliada pelo teste de esforço cardiopulmonar e classificação da New York Heart Association. Fisioter Pesqui [Internet]. 2012 [cited 2019 Feb 17];19(1):52-56. Available from: http://www.scielo.br/pdf/fp/v19n1/10.pdf

9. Bekelman DB, Rumsfeld JS, Havranek EP, Yamashita TE, Hutt E, Gottlieb SH, et al. Symptom burden, depression, and spiritual well-being: a comparison of heart failure and advanced cancer patients. J Gen Intern Med. 2009:24(5):592-8. doi: 10.1007/s11606-009-0931-y

10. Joseph SM, Cedars AM, Ewald GA, Geltman EM, Mann DL. Acute decompensated heart failure: Comtemporary medical management. Text Heart Inst J [Internet]. 2009 [cited 2019 Feb 17];36(6):510-20. Available from: https://www.ncbi.nlm.nih.gov/pmc/articles/PMC2801958/ pdf/20091200s00003p510.pdf

11. Griva M, Loucka M, Stastny J. Palliative care in cardiology. Cor et Vasa [Internet]. 2015 [cited 2019 Fev 17]; 57(1):e39-e44. Available from: https://core.ac.uk/download/pdf/82614577.pdf

12. Herr JK, Salyer J, Lyon DE, Goodloe L, Schubert C, Clement DG. Heart failure symptom relationships: a systematic review. J Cardiovasc Nurs. 2014;29(5):416-22. doi: 10.1097/JCN.0b013e31829b675e

13. Stevenson LW, Hellkamp AS, Leier CV, Sopko G, Koelling T, Warnica JW, et al. Changing preferences for survival after hospitalization with advanced heart failure. J Am Coll Cardiol. 2008;52(21):1702-8. doi: 10.1016/j.jacc.2008.08.028

14. Alpert CM, Smith MA, Hummel SL, Hummel EK. Symptom burden in heart failure: assessment, impact on outcomes, and management. Heart Fail Rev. 2017;22(1):25-39. doi: 10.1007/s107410169581-4

15. Evangelista LS, Lombardo D, Malik S, Ballard-Hernandez J, Motie M, Liao S. Examining the effects of an outpatient palliative care consultation on symptom burden, depression, and quality of life in patients with symptomatic heart failure. J Card Fail. 2012;18(12):894-99. doi: 10.1016/j.cardfail.2012.10.019

16. Nogueira IDB, Servantes DM, Nogueira PAMS, Pelcerman A, Salvetti XM, Salles F, et al. Correlation between Quality of Life and Functional Capacity in Heart Failure. Arq Bras Cardiol [Internet]. 2010 [cited 2019 Fev 17];95(2):238-43. Available from: http://www.scielo.br/pdf/abc/ v95n2/en_aop09210.pdf

17. Azevedo IG, Vieira EMA, Oliveira Neto NR, Nogueira IDB, Melo FES, Nogueira PAMS. Correlation between sleep and quality of life in patients with heart failure. Fisioter Pesq [Internet]. 2015 [cited 2019 Feb 17];22(2):148-154. Available from: http://www.scielo.br/pdf/fp/v22n2/ en_2316-9117-fp-22-02-00148.pdf

18. Cirelli MA, Lacerda MA, Lopes CT, Lopes JL, Barros ALBL. Correlations between stress, anxiety and depression and sociodemographic and clinical characteristics among outpatients with heart failure. Arch Psychiat Nurs. 2017;32(2018):235-241. doi: 10.1016/j.apnu.2017.11.008

19. Baik D, Reading M, Jia H, Grossman LV, Creber RM. Measuring health status and symptom burden using a web-based mHealth application in patients with heart failure. Eur J Cardiovasc Nurs. 2019;18(4):325-31. doi: 10.1177/1474515119825704

20. Stokdill ML, Patrician PA, Bakitas M. Understanding and measuring symptom burden in heart failure: a concept analysis. West J Nurs Res. 2019;00(0):1-25. doi: 10.1177/0193945919833710

21. Manfredini L. Tradução e validação da escala de avaliação de sintomas de Edmonton (ESAS) em pacientes com câncer avançado [Dissertação]. Brasil: Hospital de Câncer de Barretos [Internet]. 2014 [cited 2019 Feb 17]. Available from: https://www.hcancerbarretos.com. br/upload/doc/lucianamanfredini.pdf

22. Schag CC, Heinrich RL, Ganz PA. Karnofsky performance status revisited: reliability, validity, and guidelines. J Clin Oncol. 1974;2(3):187-193. doi: 10.1200/JCO.1984.2.3.187 
23. Brasil. Ministério da Saúde. Instituto Nacional de Câncer. Cancer palliative care in oncology symptom control: INCA/MS procedures. Rev Bras Cancerol [Internet]. 2002 [cited 2019 Feb 17];48(2):191-211. Available from: http://www.inca.gov.br/rbc/n_48/v02/pdf/condutas3.pdf

24. Rohde LEP, Montera MW, Bocchi EA, Clausell NO, Albuquerque DC, Rassi S, et al. Diretriz Brasileira de Insuficiência Cardíaca Crônica e Aguda. Arq Bras Cardiol [Internet]. 2018 [cited 2019 Feb 17];111(3):436-539. Available from: http://www.scielo.br/pdf/abc/ v111n3/0066782Xabc111030436.pdf

25. Mukaka MM. A guide to appropriate use of correlation coefficient in medical research. Malawi Med J [Internet]. 2012 [cited 2019 Feb 17];24(3):69-71. Available from: https://www.ncbi.nlm.nih.gov/pmc/articles/PMC3576830/pdf/MMJ2403-0069.pdf

26. Riedinger MS, Dracup KA, Brecht ML, Padilla G, Sarna L, Gans PA. Quality of life in patients with heart failure: do gender differences exist? Heart Lung [Internet]. 2001 [cited 2019 Feb 17];30(2):105-16. Available from: https://www.heartandlung.org/article/S0147-9563(01)81119-5/ abstract

27. Zambroski CH, Moser DK, Bhat G, Ziegler C. Impact of symptom prevalence and symptom burden on quality of life in patients with heart failure. Eur J Cardiovasc Nur. 2005;4(3):198-206. doi: 0.1016/j.ejcnurse.2005.03.010

28. Rose M, Anatchkova M, Fletcher J, Blank AE, Bjorner J, Lowe B, et al. Short and precise patient self-assessment of heart failure symptoms using a computerized adaptive test. Circ Heart Fail. 2012;5(3):331-9. doi: 0.1161/CIRCHEARTFAILURE.111.964916

29. Chen YT, Vaccarino V, Williams CS, Butler J, Berkman LF, Krumholz HM. Risk factors for heart failure in the elderly: a prospective communitybased study. Am J Med [Internet]. 1999 [cited 2019 Feb 17];106(6):605-12. Available from: https://www.ncbi.nlm.nih.gov/pubmed/10378616

30. Ezekowitz JA, Thai V, Hodnefield TS, Sanderson L, Cujec B. The correlation of standard heart failure assessment and palliative care questionnaires in a multidisciplinary heart failure clinic. J Pain Symptom Manage. 2011;42(3):379-87. doi: 10.1016/j. jpainsymman.2010.11.013

31. Heo SH, Moser DK, Pressler SJ, Dunbar SB, Dekker RL, Lennie TA. Depressive symptons modify relationship between inflamation and physical symptoms in patients with heart failure. Am J Crit Care. 2014:3(5):404-13. doi: 0.4037/ajcc2014614

32. Ogilvie RP, Everson-Rose SA, Longstreth Jr WT, Rodriguez CJ, Diez-Roux AV, Lutsey PL. Psychosocial Factors and Risk od Incident Heart Failure the Multi-Ethinic Study of Atherosclerosis. Circ Heart Fail. 2016;9(1):e002243. doi: 0.1161/CIRCHEARTFAILURE.115.002243

33. Dekker RL, Lennie TA, Doering LV, Chung ML, Wu JR, Moser DK.(2014). Coexisting anxiety and depressive symptoms in patients with heart failure. Eur J Cardiovasc Nurs. 2014;13(2):168-176. doi: 10.1177/1474515113519520

34. Suzuki T, Shiga T, Kuwahara K, Kobayashi S, Suzuki S, Nishimura K, et al. Impact of clustered depression and anxiety on mortality and rehospitalization in patients with heart failure. J Cardiol. 2014;64(6):456-62. doi: 10.1016/j.jjcc.2014.02.031

35. Moser DK, Worster PL. Effect of psychosocial factors on physiologic outcomes in patients with heart failure. J Cardiovasc Nurs [Internet]. 2000 [cited 2019 Feb 17];14(4):106-15. Available from: https://www.ncbi.nlm.nih.gov/pubmed/10902107

36. Johnson MJ, Bland JM, Davidson PM, Newton PJ, Oxberry SG, Abernethy AP, et al. The relationship between two performance scales: New York Heart Association classification and Karnofsky Performance Status Scale. J Pain Symptom Manage. 2014;47(3):952-8. doi: 10.1016/j. jpainsymman.2013.05.006 